\title{
Personal Dual Gender of English and Arabic Nouns in Selected Sonnets of Shakespeare and Poems of Al-Mutanabbi
} https://doi.org/10.32792/utq/utj/vol11/4/8

\author{
Kamal Gatta Nasir \\ Department of English \\ College of Education for Humanities \\ University of Thi-qar
}

\begin{abstract}
:
Personal dual gender may grammatically be defined as a category that includes nouns which can be either masculine or feminine. Moreover, it is a class of nouns, which has 'who-he or she' pronouns co-reference. This paper is an attempt to settle the confusions which surround the term 'dual gender' in English and Arabic. In addition, this work tries to show, each aside, the nouns which have the personal dual gender in the two languages. Then, the similarities and differences among the target nouns of the two languages are highlighted.
\end{abstract}

As will be seen, this paper falls into seven sections: first- The introduction of the study, second- Gender in English, third- Personal dual gender in English, fourthGender in Arabic, fifth- Personal dual gender in Arabic, sixth- Analyses of selected sonnets by Shakespeare and poems by Al-Mutanabbi: a- Shakespeare's Sonnets, b- AlMutanabbi's poems, and seventh- Conclusions.

\section{Introduction:}

The distinction between a male and female is biologically called 'Sex', and grammatically called gender. Gender in English is usually defined as a grammatical device whereby a noun, a pronoun, an article or an adjective is (masculine, feminine, dual or neutral), whereas Arabic recognizes two genders: (masculine and feminine).

Gender is embedded so thoroughly in our institutions, our actions, our beliefs, and our desires, it appears to be completely natural (Eckert \& McConnell-Ginet, 2003: 9). It is also a system of meaning - a way of construing notions of male and female and language is the primary means through which we maintain or contest old meanings, and construct or resist new ones(ibid.: 6).

Most of the careers are related to males and occupied later on by females. Without any inflection to the base of the noun, English has no problem to name both a 


\section{University of Thi-Qar Journal Vol.11 No.4 DEC 2016}

Web Site: https://jutq.utq.edu.iq/index.php/main Email: journal@jutq.utq.edu.iq

man or a woman: (Professor, Member of Parliament (M.P.), Minister, Teacher and so on).

Arabic has an unsettled problem with the nouns of professions and careers, especially for women whether: (أستاذ [Austath] or أستاذة [Austathatun] (Professor)?; عضو [Authu] or عضوة [Authuatun](Member)?; وزير [Wazir] or وزيرة [Waziratun] (Minister)?; نائبة [Na'ib] or نائبة [Natun](A Representative of Population or Member of Parliament (M.P.))?; باحث [Bahith] or باحثة [Bahithatun] (researcher)?).

On the one hand, Englishmen say: "He/ She is an active 'Member of Parliament' " (i.e. M.P. for the two genders). On the other hand, Arabs have no problem with the male gender to say:" نائب نشط ", but they could not settle whether:" نائب نشط ؟ أو نائبة نشطة " ؟, readers have to know that a word 'نائبة ' definitely means 'a disaster' in Arabic.

The problematic areas beyond the writing of this paper are: A- The absence of the term 'dual gender' in classical resources of Arabic grammar which are written in English, it is replaced by the 'common one'. B- The 'dual' term of 'gender' may be confusable with that of 'number' which means (two) in English (Crystal, 2003: 321), and in Arabic [Al-Muthana](i.e. singular, dual and plural). C- A misleading translation of 'neuter gender' into Arabic as 'Al-Muhaiid' may also be confusable with the dual/common gender 'Al- Muzdawaj'. Shedding the light on the dual gender in both languages, this paper aims to solve these confusions.

Though it is not the main concern of this paper, Wright (1971, II: 177) claims that there is no 'neuter' gender in Arabic, this paper stands against this idea only because this term and the words which belong to are discussed elaborately in a complete Arabic resource named " Mustalah Al-Muhaiid " written by Noor Al-Deen (1990). Under the titles ' tropical male' ' المذكر المجازي ' and ' tropical female' ' المؤنث المجازي 'in classical Arabic, Noor Al-Deen (1990: 5ff.) finds out the Arabic equivalent nouns to the neuter ones in English (e.g. حائط [ha'it](wall), عمل [amal] (work), نار [naar](fire),etc.), which are neither real male nor real female, they are metaphorical.

This paper hypothesizes that: A- A 'common gender' in Arabic is an equivalent to a 'dual gender' in English, B- Nouns of professions and careers in English and Arabic may involve the personal dual gender without any inflections, C- English nouns which lead to the dual gender are more in number than the Arabic ones.

This paper is limited to the investigation of the nouns with a personal dual gender in selected sonnets of Shakespeare and poems of Al-Mutanabbi. Like any contrastive study, this paper highlights the similarities and differences of the forms and the meanings of these nouns in English and Arabic. Picking up the nouns of the personal dual gender from the classical works of Shakespeare and Al-Mutanabbi, the 


\section{University of Thi-Qar Journal Vol.11 No.4 DEC 2016}

Web Site: https://jutq.utq.edu.iq/index.php/main Email: journal@jutq.utq.edu.iq

study aims to show the bilingual reader how to use the correct forms of the nouns in both languages.

Pinpointing the nouns which carry the meanings of the personal dual genders in English and Arabic respectively, this paper follows Quirk et al. (1985), Jespersen (1949) Ameen (1973), and Al-Anbari (1981) as models.

\section{Gender in English:}

Crystal (2003:197) defines gender in English as a grammatical category used for the analysis of word-classes displaying such contrasts as (masculine, feminine and neuter, animate and inanimate, etc.). Also, he differentiates between 'natural gender' which is related to sex, and 'grammatical gender' which refers to the relationship between words for example (adjectives agreeing with nouns) in a sentence. Likewise, Jespersen (1949, VII: 174) and Leech (2006: 46) emphasize that gender in English is a grammatical category and they add that English has three genders: masculine, feminine and neuter.

By the same manner, gender in English means a grammatical classification of nouns, pronouns, or other words in the noun phrase, according to certain meaningrelated distinctions, especially a distinction related to the sex of the referent (Quirk et al., 1985: 314). In English, unlike many other related languages, nouns, determiners, and adjectives have no inflectionally-marked gender distinctions (ibid.). Nouns like 'princess, poetess, businesswoman, etc.' may be marked by suffixes or compounding words though.

The terms Male and Female can be used in reference to the ' Covert ' gender of nouns, as distinct from the ' Overt ' gender of pronouns. To Quirk et al. (ibid.), gender is generally classified into: animate (personal and non-personal) and inanimate. Personal, animate gender in English involves (male, female, dual, common and collective).The main concern of this study is the 'personal dual gender'.

A good look at the definitions above reveals incompatible idea in what is related to the name of the third type of gender in English (i.e. neuter or dual?). This can be regarded as a problematic area indeed. In English, the reader has to differentiate between 'dual' in gender and 'dual' in number which means (two) (Quirk et al. (1985) and Crystal(2003: 321)).

Consequently, the term 'neuter' -which is used in the definitions above- does not cover the meaning of the class of nouns which denote the male and female gender at the same time. Thus, Leech (2006: 68) considers 'neuter' or (non-personal) having neither masculine nor feminine gender. It is a neuter pronoun, in contrast to he and she. 


\section{University of Thi-Qar Journal Vol.11 No.4 DEC 2016}

Web Site: https://jutq.utq.edu.iq/index.php/main Email: journal@jutq.utq.edu.iq

To decide 'gender' and the placement of a 'personal dual gender' in English, the coming diagram of gender classes is illustrated by Quirk et al. (1985: 314):

Gender in English

\begin{tabular}{|c|c|c|c|}
\hline \multirow{5}{*}{ animate } & Gender class & Example & $\begin{array}{c}\text { Pronoum } \\
\text { Coreference }\end{array}$ \\
\hline & (a) male & Brothet & Who- he \\
\hline & (b) female & Sister & Who-she \\
\hline & (c) dual & Doctor & Who-he/she \\
\hline & (d) Common & \multirow{2}{*}{ Baby } & Who-he/she/it \\
\hline & & & Which- it \\
\hline & (e) collective & \multirow{2}{*}{ Family } & Which-it \\
\hline & & & Who- they \\
\hline & (f) higher & \multirow{3}{*}{ Bull } & \multirow{2}{*}{ Which - it } \\
\hline & Male & & \\
\hline & Animal & & (who)- he \\
\hline & (h) higher & \multirow{3}{*}{ Cow } & \multirow{2}{*}{ (which-it) } \\
\hline & Female & & \\
\hline & Animal & & (who)-she \\
\hline & (b) lower & \multirow[t]{2}{*}{ Ant } & \multirow{2}{*}{$\begin{array}{l}\text { Which } \\
\text { (he/she) }\end{array}$} \\
\hline & Animal & & \\
\hline inan & (i) inanimate & Box & Which- it \\
\hline
\end{tabular}

- Gender classes in English taken from Quirk et al. (1985: 314)

\section{Personal Dual Gender in English:}

The personal dual gender in English is a category that includes nouns which can be either masculine or feminine. The most important feature of these nouns is that they have inherent gender which cannot be shown explicitly. Moreover, it is a class of nouns which has who-he or she pronouns co-reference, it includes nouns like:

- ( artist, foreigner, librarian, professor, student, cook, friend, novelist, servant, teacher, doctor, guest, parent, singer, typist, enemy, inhabitant, person, speaker, writer)(Quirk et al., 1985: 315),( person, spouse, parent, baby, monarch, sovereign)(Jespersen, 1949, VII: 180),( cousin, relative, friend, guest, enemy, comrade, servant, slave, outlaw, fool, criminal, prisoner, thief, dwarf, neighbour, stranger, foreigner) (Jespersen, ibid.: 192).

- Agent-nouns may include the personal dual gender: (thinker, writer, conqueror, interpreter, possessor, successor, intruder, liar, student, agent, inhabitant, copyist, 


\section{University of Thi-Qar Journal Vol.11 No.4 DEC 2016}

Web Site: https://jutq.utq.edu.iq/index.php/main Email: journal@jutq.utq.edu.iq

musician, violinist, novelist, librarian, drunkard, European, American, Norwegian, Dane, Londoner, Oxonian, Christian, Lutheran, Methodist, Mohammedan, heathen, atheist, Republican, democrat, Socialist, partisan, candidate, member) (ibid.).

- Words of social conditions which are practically always used of men only, properly belong to the two sexes (i.e. masculine and feminine): (shoemaker, baker, merchant, lawyer, soldier, general, bishop), Nowadays this is being changed with regard to words like : professor, doctor, member of parliament, Mayor, Sailor) (ibid.: 193), (Child)(ibid.: 195),( master, victor, judge) (ibid.: 196),( fellow, heir-can be heiress, hero- can be heroine) (ibid.: 197).

If it is felt desirable to give information on the sex of the pronoun, a gender marker may be added, such as male student/ female student (Quirk et al., 1985: 315). As a matter of fact, Quirk et al. (ibid.: 316) ensure that there are no rational rules that can be given for whether a noun should have dual gender or not.

\section{Gender in Arabic:}

In respect of gender, Wright (1971, II: 177) clarifies that Arabic nouns are divisible in three classes: masculine, feminine and common gender (i.e. the latter could be either masculine or feminine). Haywood and Nahmad (1993: 27), and Ryding (2005: 119) agree that there are only two genders in Arabic: masculine and feminine. Structurally or morphologically, they add that the masculine form is the simplest and most basic shape, whereas feminine nouns usually have a suffix that marks this gender.

In other words, all Arabic nouns have inherent grammatical gender. Many nouns are not marked for gender, but they have a consistent gender and a consistent gender association, just as the marked nouns do. The masculine gender is regarded as the unmarked form, while the feminine gender is the marked form (Aziz, 1989: 123). As feminine markers, the "ta' marbuta" is the usual feminine ending.

Thus, the suffix " ta' marbuta " may be added to masculine nouns or adjectives to make the feminine gender: (خادم [khadim] (servant), خادمة [khadimatun] (female servant); ابن [Ibn] (son), ابنة [ibnatun] (daughter). The resources above do not ignore that few words may be either feminine or masculine at the same time.

The survey of the literature above does not reveal all nouns that carry the meaning of the personal dual gender in Arabic. Instead, Ryding (2005: 125) mentions a small number of Arabic nouns that can be either masculine or feminine [suuq](market), طريق [tariiq] (road or path), كيس [kiis] (bag), ملح [milh] (salt), روح [ruuh] (spirit), سماء [sama'a] (sky), لسان [lisaan] (tongue), حال [haal] (condition)). 


\section{University of Thi-Qar Journal Vol.11 No.4 DEC 2016}

Web Site: https://jutq.utq.edu.iq/index.php/main Email: journal@jutq.utq.edu.iq

Explaining the classes of gender in Arabic, Aziz (1989: 124) shows the following diagram, he never declares the place of the common/dual gender within the first animate/ personal group though.

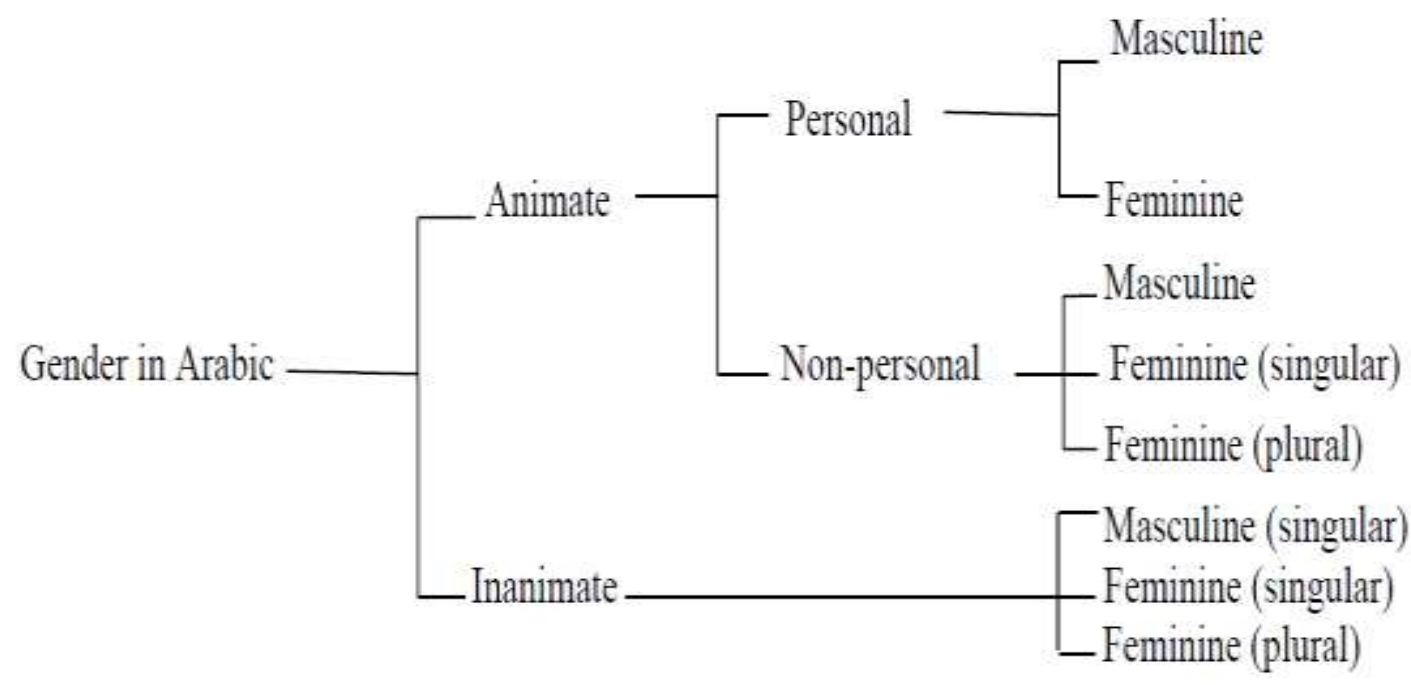

- Gender classes in Arabic taken from Aziz (1989: 124).

\section{Personal Dual Gender in Arabic:}

Right from the beginning, the reader has to have some knowledge about the term 'dual gender' in Arabic, it means ' التذكير و التأنيث المزدوج: ' [Al-Tathkiir wal Ta'niith AlMuzdawag] (Baalbaki and Baalbaki, 2010: 375, 486) (i.e. the word may commonly denote the male and female genders at the same time).

Arabic grammars, which are written in English, do not pay much attention to the nouns that have the meaning of the personal dual gender in Arabic. Ameen (1973: 96) frankly shows, with some details, the following nouns that can be dual in Arabic:

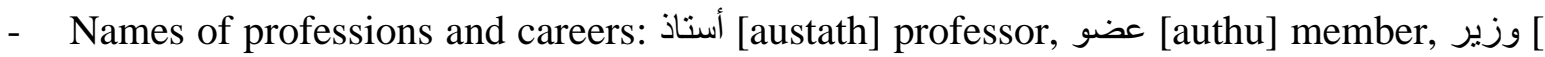
wazir] minister, رئيس [ra'iis] president, طبيب [ tabiib] physician, مدير [mudir] manager, [na'ib] deputy or vice.

- Nouns that are stationary or incapable of growth [al-asma'au al-jamidatu], they mainly should not take the feminine suffix (ta' marbuta) to alter the male gender into female, they are allowable to take this suffix in some cases though, as in: 


\section{University of Thi-Qar Journal Vol.11 No.4 DEC 2016}

Web Site: https://jutq.utq.edu.iq/index.php/main Email: journal@jutq.utq.edu.iq

إمام (Imam).

- Nouns that can be adjectives may take the feminine suffix: عضو [authu] member, ؤستاذ [austath] professor/tutor, أمير [amiir] prince, عامل [aamil] worker, وصي [wassi] trustee or executor, شاهد [wakiil] agent, مؤذن [shahid] witness, مون [mu'athin] muezzin or crier, [tabiib] physician/doctor, حسيب [hassiib] reckoner ( Ameen, ibid.: 97), he exemplifies the previous nouns as:

[ عاملنا أمر أة [aamiluna imra'atun] Our worker is a woman.

2- أميرنا أمر أة [amiiruna imra'atun] Our prince is a woman.

3- فلانة وصي فلان [fulanatu wassiu fulan] A woman is a trustee of a man.

4- فلانة وكيل فلان ] fulantu wakiilu fulan] A woman is an agent of a man.

5- مؤذن بني فلان امر أة [mu'athinu bani fulan imra'atun] The Muezzin of someone's sons is a woman.

6- فلانة شَاهد بكذا [fulanatu shahidun bi katha] A woman is a witness of this.

7- إقر أ كتابك كفى بنفسك اليوم عليك حسيبا ) (Read your book! Yourself suffices you this day as a constant-reckoner against you" (Ghali,2002: 283). In this ayaa of the glorious Quran, the noun 'حسيب' (reckoner) a male gender is used for the word 'نفس' ' (self) which has a female sense in Arabic.

8- طبيب بني أود على النأي زينبا

أ مخترمي ريب المنون و لم أزر

[ a mukhtarimi raybul manun wa lam azur

tabiibu bani 'audun ala al na'iu Zaynaba]

Ameen (1973: 99) sums up that it is mainly allowable to use the nouns or adjectives which belong to men's careers and professions for women as they are (i.e. without feminine suffix), it is allowable to use them with feminine suffix though (i.e. [w وكيلة [wakilatun] agent, وصية [wassiiyatun] trustee, etc. .

Al-Anbari (1981,1: 286-318) discusses the nouns that can be dual in Arabic, as follows : صديق [sadiiq] friend, رسول [rassool] prophet, ضيف [dhayf] guest, طفل [tifl] child, قزم [kazam] dwarf, عدو [adw] enemy, etc., these words sometimes can be feminized with the feminine suffix and other times can be adjectives in some contexts.

9- فر اقَّكِ لم أبخل و أنتِ صديقِ

فلو أنّلّكِ في يوحِ الرخاءِ سألتِني

(Al-Anbari, 1981: 287) 


\section{University of Thi-Qar Journal Vol.11 No.4 DEC 2016}

Web Site: https://jutq.utq.edu.iq/index.php/main Email: journal@jutq.utq.edu.iq

$$
\text { فأبلغ أبا بكرٍ رسولًِ سريعةً }
$$

(ibid.: 289)

11- رجل عدوّ و أمرأةٌ عدوّ [ rajulun aduun wa imra'atun aduun] Enemy man and enemy woman (ibid.: 317).

Other nouns, خليفة [khalifatun] (caliphate), زلطان [zaugun] (spouse), شلية [sultanun] (sultan), إنسان [insanun] or بشر [basharun] (man or person), imply a dual gender too.

\section{Analyses of Selected Sonnets of Shakespeare and Poems of Al-Mutanabbi:}

This section is devoted to the investigation of the nouns which carry the personal dual gender in the English and Arabic classical selected works of Shakespeare and Al-Mutanabbi. Shakespeare's sonnets are compiled by Azevedo (2014). As the numbers of Shakespeare's sonnets are well known to readers, this research refers to the numbers of the sonnets, not the numbers of the pages in the compiled book. Besides, all of Al-Mutanabbi's poems are translated into English by Wormhoudt (2002).

\section{A- Shakespeare's Sonnets:}

1- $\quad$ "To me, fair friend you never can be old,

For as you were when first your eye I eyed." (Sonnet: 104).

2- $\quad$ "But if the while I think on thee, dear friend,

All losses are restored and sorrows end." (Sonnet: 30$)$.

The two quotations above of the English sonnets involve the noun 'friend', it carries the personal dual gender (i.e. male or female, especially in the poetic language). The poet in the two sonnets above describes his lover as a 'friend'. This noun can syntactically be replaced by the pronouns 'who-he or she' (i.e. dual gender).

3- $\quad$ "And art made tongue-tied by authority,

And folly doctor-like controlling skill," (Sonnet: 66).

Grammatically, the English noun of profession 'doctor' in the sonnet above can be used to mean a dual gender (i.e. a man or woman).

4- $\quad$ "Another time mine eye is my heart's guest,

And in his thoughts of love doth share apart:" (Sonnet: 47).

5- $\quad$ "I, sick withal, the help of bath desired, 


\section{University of Thi-Qar Journal Vol.11 No.4 DEC 2016}

Web Site: https://jutq.utq.edu.iq/index.php/main Email: journal@jutq.utq.edu.iq

And thither hied, a sad distempered guest," (Sonnet: 153).

The English noun 'guest' in the two quotations above includes the meanings of a male and female gender, it can be replaced by the pronouns 'he' or 'she'. The poet in the lines above uses 'guest' once for his eye, which has mainly a meaning of a female, another for a male (i.e. the poet himself).

6- $\quad$ "The dedicated words which writers use

of their fair subject, blessing every book." (Sonnet: 82).

Writers may be males or females, thus the English noun 'writer' has no suffixation to be inflected from the male into the female gender. Furthermore, this nouns can be normally replaced by the pronouns 'he' or 'she'.

7- $\quad$ " Or whether doth my mind, being crowned with you,

Drink up the monarch's plague, this flattery?" (Sonnet: 114).

The English noun 'monarch' denotes a person (male or female) who rules a country, so it has a personal dual gender. As usual, this noun would not be inflected/ suffixed to change the male gender into female one.

8- $\quad$ " Nor dare I chide the world-without-end hour

Whilst I, my sovereign, watch the clock for you, " (Sonnet: 57).

The English noun 'sovereign' lexically means either a king or a queen. This noun grammatically carries a personal dual gender. In the sonnet above, the word 'sovereign' describes the poet's lover.

9- " Then, soul, live thou upon thy servant's loss,

And let that pine to aggravate thy store;" (Sonnet: 146).

10- " Nor think the bitterness of absence sour

When you have bid your servant once adieu." (Sonnet: 57).

Gender of the English noun 'servant' is dual, can definitely be used for either a 


\section{University of Thi-Qar Journal Vol.11 No.4 DEC 2016}

Web Site: https://jutq.utq.edu.iq/index.php/main Email: journal@jutq.utq.edu.iq

male or a female. Thus, the two subjective pronouns 'he' or 'she' may normally replace it. The two sonnets use this noun to indicate the poet's lover who served his soul and left.

11- " Being your slave, what should I do but tend

Upon the hours and times of your desire?" (Sonnet: 57).

12- " Is 't not enough to torture me alone,

But slave to slavery my sweet'st friend must be?" (Sonnet: 133).

The two sonnets above include the English noun 'slave' which has a personal dual gender, it may be replaced by the pronouns 'he' or 'she'. The poet in the lines above indicates himself by a 'slave'.

13- " So true a fool is love that in your will

(Though you do anything) he thinks no ill." (Sonnet: 57).

14- " To this I witness call the fools of Time,

Which die for goodness, who have lived for crime." (Sonnet: 124).

The fools of love, whom the poet talks about, may be either males or females. Grammatically the English 'fool' has a personal dual gender, it denotes both of the subject pronouns 'he' or 'she'.

15- " Then, were not summer's distillation left,

A liquid prisoner pent in walls of glass," (Sonnet: 5).

In the same manner, as dual gender, the English noun 'prisoner' includes either the male or female gender. Though the poet does not tell from the beginning that a 


\section{University of Thi-Qar Journal Vol.11 No.4 DEC 2016}

Web Site: https://jutq.utq.edu.iq/index.php/main Email: journal@jutq.utq.edu.iq

flower, which has a sense of a female, is a prisoner, he speaks frankly in the pre-final line of the sonnet (5): "But flowers distill'd though they with winter meet".

16- $\quad$ " That I an accessary needs must be [sic.]

To that sweet thief which sourly robs from me." (Sonnet: 35 ).

17- $\quad$ I do forgive thy robb'ry, gentle thief,

Although thou steal thee all my poverty;" (Sonnet: 40).

A 'thief' is chiefly a noun related to a male gender, but it may be, as in the two sonnets above, combined to some adjectives as female markers like (sweet and gentle thief) to mean a female gender. Grammatically the English word 'thief' has the meaning of the personal dual gender, it can be replaced by the personal pronouns 'he' or 'she', according to the addressee.

18- " How much more praise deserved thy beauty's use,

If thou couldst answer, "This fair child of mine..." (Sonnet: 2)

19- " But were some child of yours alive that time,

You should live twice, in it and in my rhyme." (Sonnet: 17).

Grammatically, the lines above mention the English noun 'child' which involves the personal dual gender, it is usually used in English when the sex of the baby is undecided. Thus, it may be replaced by 'he' or 'she'.

20- $\quad$ " A woman's face with Nature's own hand painted

Hast thou, the master-mistress of my passion;" (Sonnet: 20). 


\section{University of Thi-Qar Journal Vol.11 No.4 DEC 2016}

Web Site: https://jutq.utq.edu.iq/index.php/main Email: journal@jutq.utq.edu.iq

Poetically, the sonnet above depicts how a woman's face and beauty have the 'master' rank in the poet's passion. Grammatically, the noun 'master' above coincides with the female gender, it may chiefly relate to a male profession though.

21- " Thou hast pass'd by the ambush of young days,

Either not assailed or victor being charged;" (Sonnet: 70).

22- $\quad$ " As victors of my silence cannot boast;

I was not sick of any fear from thence." (Sonnet: 86).

In literature, the noun 'victor' means the winner of a battle, competition, game ... etc., a winner may be a male or female. The lines above include the English noun 'victor' which denotes the dual gender/ the male or female. Thus, it can be surely replaced by the personal pronouns 'he' or 'she' with no harm in meaning.

\section{B- $\underline{\text { Al-Mutanabbi's Poems: }}$}

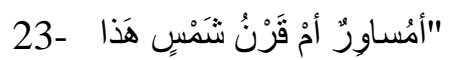

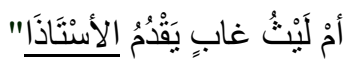

(Al-Mutanabbi, 1983: 69)

" Is this Musawar, or the sun's horn, or

The jungle lion who precedes the viceroy?" (Wormhoudt, 2002: 73).

24-

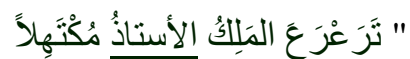

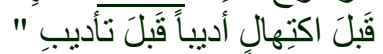

(Al-Mutanabbi, ibid.: 450)

" The royal tutor grew up and was mature

Before maturity, cultured before educated" (Wormhoudt, ibid.: 425).

The Arabic noun 'أستاذ' [austath] (tutor) may grammatically indicate either the male or female genders. In the lines above, this noun refers to the male gender. For the 


\section{University of Thi-Qar Journal Vol.11 No.4 DEC 2016}

Web Site: https://jutq.utq.edu.iq/index.php/main Email: journal@jutq.utq.edu.iq

female's profession, this noun is allowable to take the suffix " ta' marbuta" to be 'استاذة'. The noun 'أستاذ' [austath] is also used when either a male or a female has the 'professor' academic degree, the use of the suffix 'ta' marbuta' with a female gender in the last case is unusual in the formal documents.

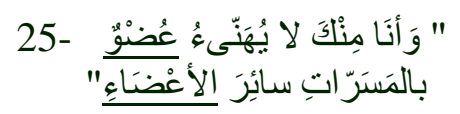

(Al-Mutanabbi, 1983: 446)

" I am not a limb to rejoice for you

With rejoicing of the other limbs" (Wormhoudt, 2002: 421).

The Arabic noun "عُضْو" [authu] 'limb or member' is related to human body, from which the social or political noun Member of Parliament or Party has been derived. Socially and politically, the Arabic noun "عُضْو [authu] may express either of the two genders (i.e. male or female). As a profession, this noun implies a personal dual gender, it may take the suffix " ta' marbuta" with a female gender "'عُضْوة " [authuatu] though.

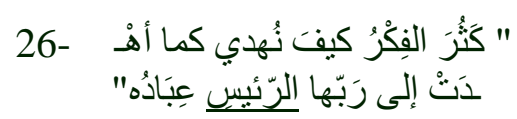

(Al-Mutanabbi, ibid.: 530)

"Thoughts are many how we are guided

As his slaves are guided to their country" (Wormhoudt, 2002: 499).

$27-$

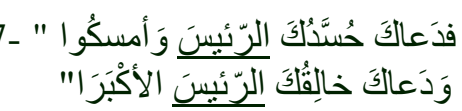

(Al-Mutanabbi, 1983: 524)

"Those who envy, call you lord now

But your Creator calls you great chief" (Wormhoudt, ibid.: 495).

In the two poems above, the Arabic noun of profession or career "رئيس" [ra'iis] (lord, chief, president or sovereign) is used three times. Every time, it has a personal dual gender, may be suffixed with " ta' marbuta" only for the female gender" "رئيسة

$28-$

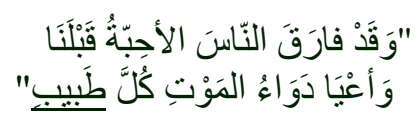

(Al-Mutanabbi, ibid.: 322)

" Folk before this have parted from lovers 


\section{University of Thi-Qar Journal Vol.11 No.4 DEC 2016}

Web Site: https://jutq.utq.edu.iq/index.php/main Email: journal@jutq.utq.edu.iq

Death's illness exhausts every physician" (Wormhoudt, 2002: 307).

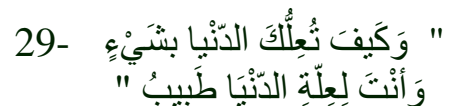

(Al-Mutanabbi, 1983: 362)

" How could a world make you sick now

When you are doctor to the world's ills?" (Wormhoudt, ibid.: 345).

In Arabic, the noun of a career or profession "طَبيبـ [tabiib] (physician or doctor) carries the meaning of the personal dual gender (i.e. male or female). For the female gender in Arabic, it is allowable to use the suffix " ta' marbuta " with this noun "طَبيبة" [tabiibatu] (female physician or doctor). As given in the poetic lines above, this noun is clearly related to the male gender.

$30-$

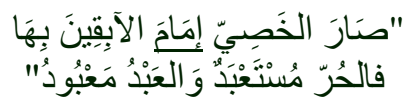

(Al-Mutanabbi, 1983: 507)

" A eunuch leader of runaway slaves

The free man enslaved, slave obeyed" (Wormhoudt, 2002: 463).

$31-$

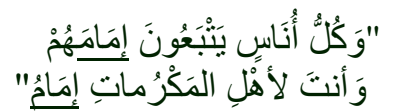

(Al-Mutanabbi, 1983: 392)

" All men followed their leadership

You were leader of folk of noble deeds" (Wormhoudt, 2002: 371).

As seen in the two poems above, the Arabic noun " إمام " [Imam] is one of [alasma'au al-jamidatu], which rarely be combined to the suffix " ta' marbuta ". Thus, this Arabic noun, as a personal dual gender, may consequently be replaced by the personal pronouns 'he' or 'she'.

With regard to the previous translations of this noun into English, it is misleadingly translated into 'leader'. In fact, the Arabic noun " إماح " [Imam] is nowadays borrowed into English, because the word 'leader' does not convey its real religious, social and cultural meanings.

$32-$

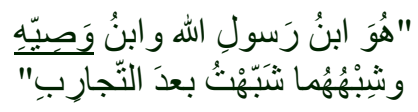

(Al-Mutanabbi, ibid.: 228) 


\section{University of Thi-Qar Journal Vol.11 No.4 DEC 2016}

Web Site: https://jutq.utq.edu.iq/index.php/main Email: journal@jutq.utq.edu.iq

"God's rasul's son, executor's son

Comparison for them matched to fact" (Wormhoudt, ibid.: 221).

In the same manner of analysing the previous quotations, the Arabic noun ' ' [wasii] (executor) may indicate a personal dual gender in Arabic. The poet here refers to, male gender, the Prophet Muhammad's Executor: Ali Bin Abi-Talib (P.B.U.H.). As seen in the literature of this paper, it is allowable for the female gender to take the suffix " ta' marbuta " ' وصية ' [wasiiatu] (Ameen, 1973: 99). This last word is likened to another one which denotes a Muslim's 'Will' which he/she usually writes before death.

$33-$

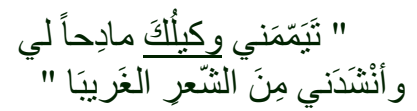

(Al-Mutanabbi, ibid.: 169)

"Your manager came to me to praise

He recited to me some strange verses" (Wormhoudt, 2002: 189).

By the same token, this poem has the Arabic noun ' وكيل' [wakiil] (manager or representative) which can be used for either a male or female gender, it denotes the personal dual gender. To approximate the meaning of the poem to readers, the Arabic verb ' تيمنني ' [tayamamani] above means ' came to me ' (Al-Mutanabbi, 1983: 169).

$34-$

$$
\begin{aligned}
& \text { "وَلِيتَ يَوْمَنْ فَفَاءِ عَسْكَرِهِ }
\end{aligned}
$$

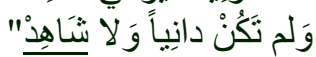

(Al-Mutanabbi, 1983: 553)

"You gave two days to his army's ruin

You were neither victor not a witness" (Wormhoudt, 2002: 523).

$35-$

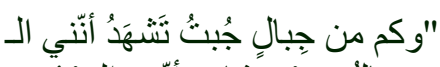

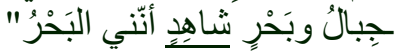

(Al-Mutanabbi, ibid.: 190)

"Many a mountain I crossed to witness

I was mountain, seas, I was the sea wave" (Wormhoudt, ibid.: 185).

These poems show the Arabic noun ' شاهد ' [shahid] (witness) which stands for the male gender, it may also include the female gender in other texts. Thus, it carries the meaning of a personal dual gender. For the female gender, this noun may or may not be combined with the suffix " ta' marbuta " ' شاهدة ' [shahidatun]. 


\section{University of Thi-Qar Journal Vol.11 No.4 DEC 2016}

Web Site: https://jutq.utq.edu.iq/index.php/main Email: journal@jutq.utq.edu.iq

$$
\text { وَإنْ كَثُرَتْ في عَينِ مَن لا يجرّبُ" }
$$

(Al-Mutanabbi, ibid.: 467)

"Horses like friends are only too few

Though they are many to an untrained eye" (Wormhoudt, 2002: 441).

$37-$

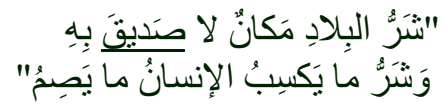

(Al-Mutanabbi, ibid.: 333)

"Worst land a place with no friend

The worst one can earn is what dishonours," (Wormhoudt, ibid.: 317).

As known socially and grammatically, a 'friend' can be either a male or female. Like some previous nouns, the Arabic noun 'صديق' can be inflected with suffix " ta' marbuta " to show the female gender. In addition, like English, it may be replaced by the pronouns 'he' or 'she' (e.g. He/ She is a good friend - هو / هي صديق جيد).

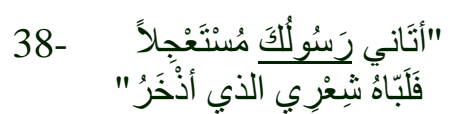

(Al-Mutanabbi, 1983: 354)

"Your messenger came to me in haste

So I answered him with my stored verses" (Wormhoudt, 2002: 337).

39-

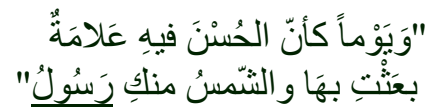

(Al-Mutanabbi, ibid.: 356)

"It was a day as if beauty was its token

You sent out, the sun was your messenger" (Wormhoudt, ibid.: 341).

As a matter of fact, the Arabic noun ' رسول' [Rassool] (Messenger) is one of the nouns that are stationary or incapable of growth [al-asma'au al-jamidatu], it definitely should not take the feminine suffix (ta' marbuta) to alter the male gender into female. As a personal dual gender, this noun syntactically sticks to the same form for the male and female gender.

Furthermore, a good look at the two preceding quotations of this paper reveals that the Arabic noun ' رسول ' in quotation (38) refers to a man as a messenger (i.e. male gender), whereas in quotation (39) it refers to the beauty and sun as messengers from 


\section{University of Thi-Qar Journal Vol.11 No.4 DEC 2016}

Web Site: https://jutq.utq.edu.iq/index.php/main Email: journal@jutq.utq.edu.iq

the poet's lover (i.e. female gender). Al-Anbari(1981, 1: 301) asserts the feminine sense of the word ' شمس ' 'sun' in Arabic.

$40-$

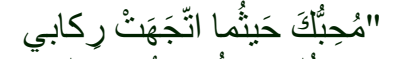

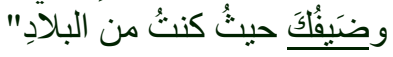

$$
\begin{aligned}
& \text { (Al-Mutanabbi, ibid.: 88) }
\end{aligned}
$$

"Your lover where my steed turns itself

And your guest wherever I am in any hand" (Wormhoudt, ibid.: 89).

$41-$

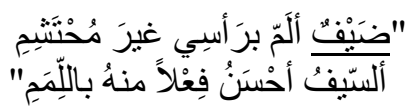

(Al-Mutanabbi, ibid.: 36)

"A guest without shame lights on my head

The sword would do this better for my braids" (Wormhoudt, ibid.: 39).

One of the Arabic nouns, which denote the personal dual gender, is ' ضيف ' [dhayf] (guest). It is allowable for this noun to take the feminine suffix " ta' marbuta " ' ضيفة '[dhayfatu]. In the two quotations above, this noun once symbolises a man in quotation (40), and another a white hair in quotation (41).

$42-$

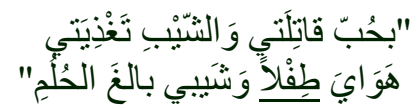

(Al-Mutanabbi, 1983: 36)

"My foe fed me with love and white hair

My love was childish, my gray was puberty" (Wormhoudt, 2002: 39).

43-

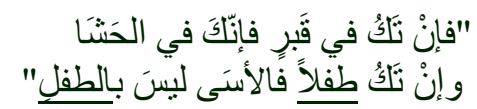

(Al-Mutanabbi, ibid.: 279)

"If you are entombed, it is in the heart

If you were a child, grief is not for children" (Wormhoudt, ibid.: 269).

The Arabic noun ' طفل ' [tifl] (child) may indicate either of the two genders (male or female); therefore, it signifies a personal dual gender. Moreover, the female gender of this noun may be inflected by the suffix " ta' marbuta " ' طفلة ' [tiflatu].

$44-$

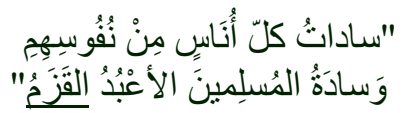




\section{University of Thi-Qar Journal Vol.11 No.4 DEC 2016}

Web Site: https://jutq.utq.edu.iq/index.php/main Email: journal@jutq.utq.edu.iq

(Al-Mutanabbi, 1983: 502)

"Rulers of people come from themselves

But the ruler of Muslims is the beast slave" (Wormhoudt, 2002: 459).

The poet in this line uses the Arabic noun 'قزم' [qazam] (dwarf) metaphorically to endow the Muslim rulers (at that time) the features of a 'beast and vile'. As dual gender, this noun stands for either a male or female. As a fact, Al-Anbari (1981, 1: 305) ensures the meaning of the dual gender of this Arabic noun 'قزم ' which structurally accepts no inflection to be altered from the male to the female gender.

$45-$

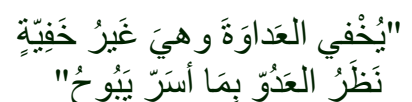

(Al-Mutanabbi, ibid.: 68)

"One veils enmity, it cannot be concealed

The enemy glance reveals what is a secret" (Wormhoudt, ibid.: 71).

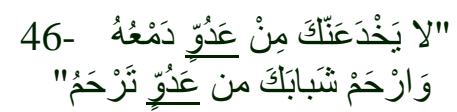

(Al-Mutanabbi, 1983: 571)

"Let not tears of a friend deceive you

Pity your youth instead of a foe you pity" (Wormhoudt, 2002: 225).

Since it indisputably refers to the male and female genders, the Arabic noun ' ' [adw] (enemy) implies a personal dual gender. For the female, this noun may accept the suffix " ta' marbuta " عدوة' [adwwatun]( female enemy). This Arabic noun is amazingly translated into English 'friend' in quotation (46) above.

$47-$

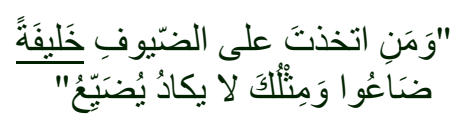

(Al-Mutanabbi, ibid.: 493)

"Who takes you as deputy for guests

Who lose their way while you remain?" (Wormhoudt, ibid.: 479).

$48-$

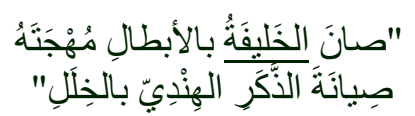

(Al-Mutanabbi, ibid.: 275)

"A caliph guards his blood with heroes 


\section{University of Thi-Qar Journal Vol.11 No.4 DEC 2016}

Web Site: https://jutq.utq.edu.iq/index.php/main Email: journal@jutq.utq.edu.iq

Cherishing Indian steel with a scabbard" (Wormhoudt, ibid.: 265).

A personal dual gender occurs apparently in the Arabic noun ' خليفة ' [khalifa] (caliph, deputy), it may denote either a male or a female gender. Moreover, this Arabic noun may be distinguished from other nouns, which denote the personal dual gender, by the existence of the feminine suffix "ta' marbuta" at the end of the root of the word. This noun as a result has no inflections for altering the male into female gender and viceversa.

49-

$$
\begin{aligned}
& \text { "وَكَلامُ الوُشَََاةِ لَيسَ على الأحْ }
\end{aligned}
$$

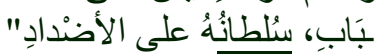

(Al-Mutanabbi, ibid.: 463)

"A slanderer's word had no power

Over the lover and was to the contrary" (Wormhoudt, ibid.: 437).

These lines include the Arabic noun ' سلطان ' [Sultan] (Monarch) which signifies the personal dual gender. This noun of a profession or career is mainly related to males, it may take the feminine suffix "ta' marbuta" to denote the female gender though.

$50-$

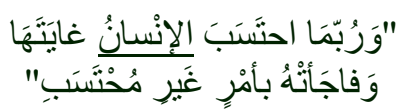

(Al-Mutanabbi, 1983: 436)

"Often a man thinks he gains by them

But they surprise with the unexpected" (Wormhoudt, 2002: 407).

$51-$

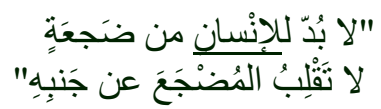

(Al-Mutanabbi, 1983: 557)

"No escape from that couch

No turning one's side from that bed" (Wormhoudt, 2002: 519).

As dual gender, the Arabic noun ' إنسان ' [insan] (man) refers to a person, either male or female. It may be inflected, by using the "ta' marbuta", to indicate the female gender ' إنسانة ' [insanatu] (woman).

$52-$

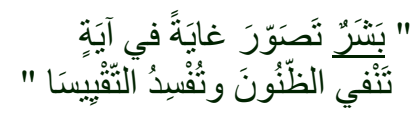

(Al-Mutanabbi, ibid.: 59) 


\section{University of Thi-Qar Journal Vol.11 No.4 DEC 2016}

Web Site: https://jutq.utq.edu.iq/index.php/main Email: journal@jutq.utq.edu.iq

"A man who depicts the heights of miracle

He baffles thought and corrupts comparison" (Wormhoudt, ibid.: 63).

$53-$

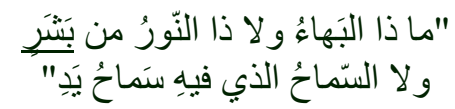

(Al-Mutanabbi, ibid.: 65)

"This glory, this light is not of mankind

Nor is generosity in it bounty of the hand" (Wormhoudt, ibid.: 69).

The last Arabic noun in this paper, which may indicate the personal dual gender, is ' بشر ' [bashar] (man or person). As female gender, this noun has no feminine form. When combined to the feminine suffix "ta' marbuta", this Arabic word alters to other different meaning ' بشرة ' [bashara] (skin).

\section{Conclusions:}

The investigations of the English and Arabic nouns in the sonnets and poems above prove that all these nouns share the feature of the 'personal dual gender'. Since the Arabic nouns lead to the same results of the English ones, then the Arabic 'common gender' is an equivalent to the English 'dual gender'. Thus, the term 'dual gender' is valid to be used instead of the 'common one' in Arabic.

Likewise, English and Arabic 'dual' genders may be distinguished easily in the nouns which relate to the professions and careers. Unlike the neuter gender which refers to a tropical male or female, the dual gender refers to real masculine and feminine nouns. Through the collected data in the literature of this paper, English nouns, which lead to the personal dual gender, are more than the Arabic ones.

English nouns, on the one hand, have no markers to distinguish the male from the female gender, they may sometimes be combined to the words like 'female' or 'male' as markers to pinpoint the type of gender (e.g. female doctor, male doctor; female teacher, male teacher). Arabic nouns, on the other hand, have the suffix " ta' marbuta " sometimes to distinguish the female from the male gender. In fact, nouns of professions and careers may or may not take the suffix " ta' marbuat " in Arabic, they take this suffix when they can function as adjectives, but they do not when they are stationary or incapable of growth [al-asma'au al-jamidatu](e.g. إمام [imam], أستاذ [Austath] (tutor), عضو [authu] (member).

The analyses of the samples in this paper declare: on the one hand, the specific nouns which denote the personal dual gender in Shakespeare's sonnets: (friend, doctor, guest, writer, monarch, sovereign, servant, slave, fool, prisoner, thief, child, master, and victor). On the other hand, the nouns in Al-Mutanabbi's poems: (أستاذ وصو -tutor,

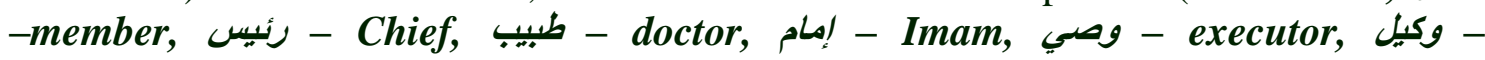




\section{University of Thi-Qar Journal Vol.11 No.4 DEC 2016}

Web Site: https://jutq.utq.edu.iq/index.php/main Email: journal@jutq.utq.edu.iq

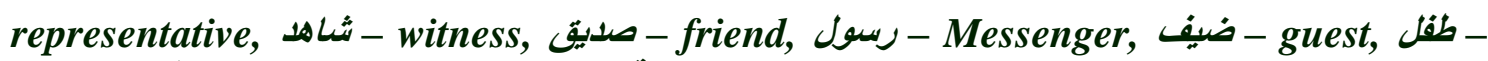

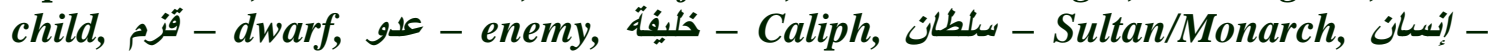
man/person, بشّ-person/man).

Again, from the analyses of these sonnets and poems, as evidence to the validity and the correlation of the terms 'dual gender' in English and 'common gender' in Arabic, some nouns are commonly found in the investigated samples of the two languages such as: (friend - صديق, doctor - طبيب, monarch - سلطان, sovereign- رئيس, guest- ضيف, and child- طفل). 


\section{University of Thi-Qar Journal Vol.11 No.4 DEC 2016}

Web Site: https://jutq.utq.edu.iq/index.php/main Email: journal@jutq.utq.edu.iq

\section{References:}

Al-Anbari, Abu Bakr (1981).Al-Muthakar wal Mu'anath.P.1.Cairo: Matabi' Al-Ahram Al-Tijariya.

Al-Mutanabbi, Abu Al Tayyib Ahmad (1983).Diwan Al-Mutanabbi (Arabic). Beirut: Beirut Printing House.

Ameen, Muhammad Shawqi (1973). 'Al-Mu'anath kal-Muthakar fii Alqaab Al-Manasib wal Al-A'maal' in Majallat Majma' Al-Lughatul Arabyya.Part 32. Cairo: Majma' Al-Lughatul Arabiya, p. 96-99.

Azevedo, Neil (2014). The Sonnets of William Shakespeare. Omaha: William Ralph Press.

Aziz, Yowell (1989). A Contrastive Grammar of English and Arabic. Mosul: Mosul University press.

Baalbaki, Munir \& Ramzi M. Baalbaki (2010). Al-Mawrid Al-Hadeeth (A Modern English-Arabic Dictionary). Beirut: Dar El-Ilm Lilmalayin.

Crystal, David (2003). A Dictionary of Linguistics and Phonetics. London: Blackwell Publishing.

Eckert, Penelope \& Sally McConnell-Ginet (2003).Language and Gender. Cambridge: C.U.P.

Ghali, Muhammad ( 2002 ). Towards Understanding The Ever Glorious Quran. Cairo:

Dar An-NashrLiljami'at.

Haywood, J. A. and H. M. Nahmad.( 1993). A New Arabic Grammar of the Written Language. London: Lund Humphries.

Jespersen, Otto (1949). A Modern English Grammar on Historical Principles.P.VII. Copenhagen: Enjar Munksgaard (EM).

Leech, Geoffrey (2006). A Glossary of English Grammar. Edinburgh: Edinburgh University Press.

Noor Al-Deen, Isam (1990). Mustalah Al-Muhaiid (Al-Muthakar wal Mu'anath AlMajazyyan). Beirut: Dar Al-Kitab Al-Aalami. 


\section{University of Thi-Qar Journal Vol.11 No.4 DEC 2016}

Web Site: https://jutq.utq.edu.iq/index.php/main Email: journal@jutq.utq.edu.iq

Quirk, Randolph; Sidney Greenbaum; Geoffrey Leech; and Jan Svartvik (1985). $\underline{\text { A }}$

Comprehensive Grammar of The English Language. London: Longman.

Ryding, Karin (2005). Modern Standard Arabic. Cambridge: C.U.P.

Wormhoudt, Arthur (trans.) ( 2002). The Diwan of Abu Tayyib Ahmad Ibn Al-Husayn Al-Mutanabbi. ABC International Group, Inc.

Wright, William (1971). A Grammar of the Arabic Language. Vol.I, P. II. Cambridge: C.U.P. 


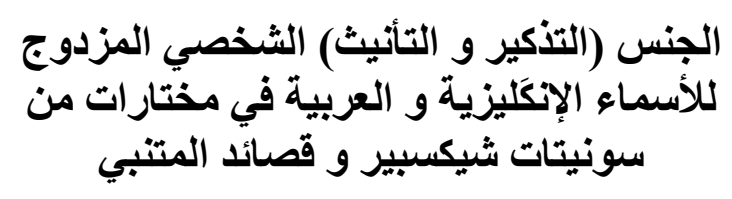

كمال كَاطع ناصر

قسم اللغة الإنكَليزية

كلية التربية الإنسانية

جامعة ذي قار

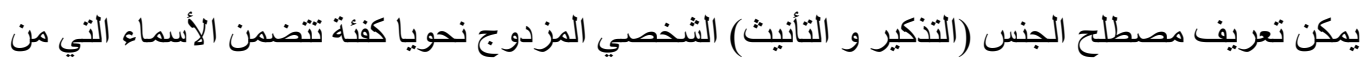

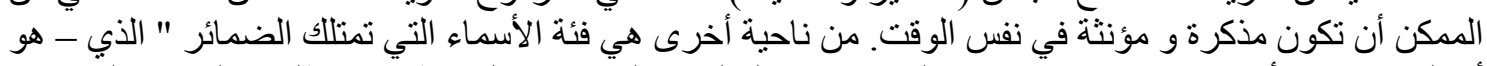

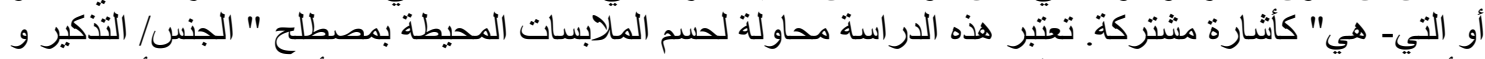

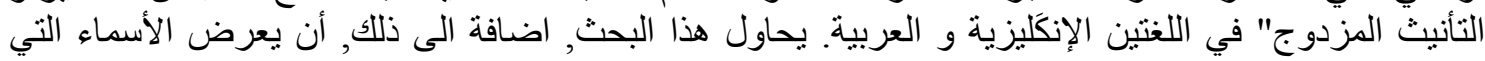

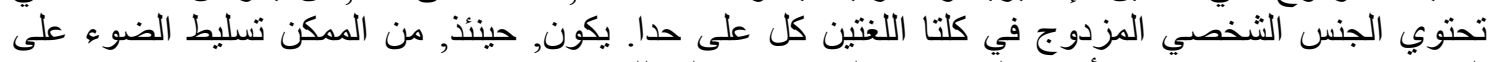

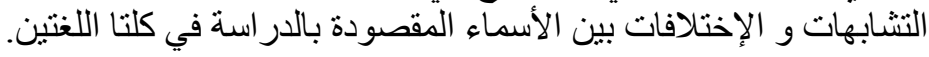

تقع هذه الدراسة, كما هو مُلاحظ, في سبع فقرات: الأولى- مقدمة الدراسة, الثانيةـ الجنس (التذكير و

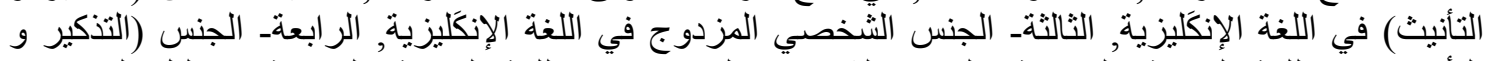

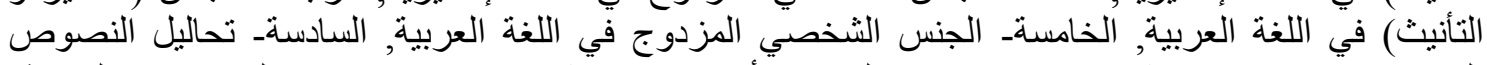

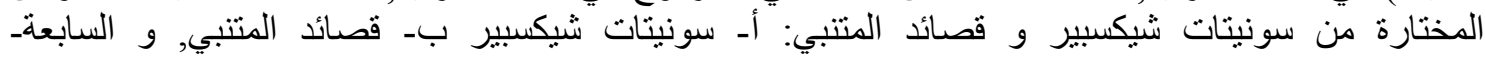

